\title{
"Fair Use" through Fundamental Rights in Europe: When Freedom of Artistic Expression allows Creative Appropriations and Opens up Statutory Copyright Limitations
}

\author{
Christophe Geiger \\ Centre for International Intellectual Property Studies (CEIPI), University of Strasbourg, \\ christophe.geiger@ceipi.edu
}

Follow this and additional works at: https://digitalcommons.wcl.american.edu/research

Part of the Intellectual Property Law Commons, and the International Trade Law Commons

\section{Recommended Citation}

Geiger, Christophe. "'Fair Use' through Fundamental Rights in Europe: When Freedom of Artistic Expression allows Creative Appropriations and Opens up Statutory Copyright Limitations." (2020) PIJIP/ TLS Research Paper Series no. 63. https://digitalcommons.wcl.american.edu/research/63

This Article is brought to you for free and open access by the Program on Information Justice and Intellectual Property and Technology, Law, \& Security Program at Digital Commons @ American University Washington College of Law. It has been accepted for inclusion in Joint PIJIP/TLS Research Paper Series by an authorized administrator of Digital Commons @ American University Washington College of Law. For more information, please contact DCRepository@wcl.american.edu. 


\title{
“FAIR USE” THROUGH FUNDAMENTAL RIGHTS IN EUROPE: WHEN FREEDOM OF ARTISTIC EXPRESSION ALLOWS CREATIVE APPROPRIATIONS AND OPENS UP STATUTORY COPYRIGHT LIMITATIONS
}

Forthcoming in: Shyamkrishna Balganesh, Wee Loon Ng-Loy, Haochen Sun (eds.), The Cambridge Handbook of Copyright Limitations and Exceptions, Cambridge University Press, 2020, 174.

\section{Christophe Geiger*}

\begin{abstract}
This chapter discusses the evolution in jurisprudential understanding of the relationship between copyright and freedom of artistic expression in the European Union. It demonstrates how courts in France and several other EU member states have accepted a "fair use" approach that applies fundamental rights as external limitations to copyright law, in compliance with the case law of the European Court of Human Rights but contrasting with the recent conflicting position of the Court of Justice of the European Union. The chapter first analyses the application of freedom of artistic expression to copyright law on a case-by-case basis and shows that, although long contested, such an approach is now mandated by EU primary law, thus "flexibilizing” significantly the legal framework in this area. It then examines the balancing act between fundamental rights and copyright, with particular attention paid to the weight the judiciary should afford freedom of artistic expression versus copyright law in cases of creative appropriation, in order to comply with the obligations resulting from European, national, and international human rights provisions. Finally, the chapter concludes with a discussion and evaluation of the growing need for legislative reform to render freedom of artistic expression fully compatible with copyright law in the context of creative reuses of protected works.
\end{abstract}

\footnotetext{
* Christophe Geiger is a Professor of Law, Director General and Director of the Research Department of the Centre for International Intellectual Property Studies (CEIPI), University of Strasbourg (France); Affiliated Senior Researcher at the Max Planck Institute for Innovation and Competition (Munich, Germany) and Spangenberg Fellow in Law \& Technology at the Spangenberg Center for Law, Technology \& the Arts, Case Western Reserve University School of Law (Cleveland, US). The author is very thankful to Luisa Pieroni, legal intern at the CEIPI, for her great editorial support and her research assistance while elaborating this chapter.
} 
ABSTRACT

INTRODUCTION

I. FAIR USE THROUGH THE APPLICATION OF FREEDOM OF ARTISTIC EXPRESSION TO COPYRIGHT ON A CASE-BY-CASE BASIS: A QUESTION (FINALLY) RESOLVED. 8

II. FAIR USE THROUGH FUNDAMENTAL RIGHTS BALANCING: WEIGHING FREEDOM OF ARTISTIC EXPRESSION AND COPYRIGHT IN CASES OF CREATIVE APPROPRIATION 13

A. Finding a fair balance between copyright and freedom of artistic expression in national courts: towards the legitimization of creative reuses of copyrighted works 13

B. Resistance to change: the Koons v. Bauret-decisions and judgement of remittal in Klasen.

1. The judgment of the Paris District Court on March 9, 2017 in Koons v Bauret. 17

2. Decision to remit Klasen to the Versailles Court of Appeal. 22

III. BEYOND FAIR USE: RENDERING FREEDOM OF ARTISTIC EXPRESSION FULLY COMPATIBLE WITH COPYRIGHT PROTECTION THROUGH LEGISLATIVE REFORM

\section{INTRODUCTION}

It is often assumed that an open-ended limitation to copyright, such as the fair use defense, is alien to the civil law tradition as it gives too much power to judges to design the contours of copyright law on a case-by-case basis. ${ }^{1}$ However, the increasing use of fundamental rights in copyright disputes in many civil law countries is challenging that assumption, raising the question of whether a sort of "fair use" limitation is not already being wielded through the weighing of interests and use of the proportionality test, both of which are required when the judiciary is applying fundamental rights. ${ }^{2}$ It will be shown in this chapter that even in France, traditionally considered an exemplar of civil

${ }^{1}$ P. Bernt Hugenholtz \& Martin R.F. Senftleben, Fair Use in Europe: In Search of Flexibilities 4 (Amsterdam Law Sch. Research Paper No. 2012-39; Inst. for Info. Law Research Paper No. 2012-33, 2012) ("[F]air use in Europe is often regarded as an oxymoron or even a taboo in classic author's rights doctrine.”).

${ }^{2}$ Already advocating that the use of fundamental rights opens up the closed list of statutory limitations through the use of the proportionality requirement, creating an open ended limitation to copyright law, see CHRISTOPHE GEIGER, DROIT D'AUTEUR ET DROIT DU PUBLIC À L'INFORMATION, APPROCHE DE DROIT COMPARÉ 391 (2004). For further discussion about the principle of proportionality and its consequences, see Jonas Christoffersen, Human Rights and Balancing: The Principle of Proportionality, in RESEARCH HANDBOOK ON HuMAN RightS AND INTELlECTUAl PROPERTY 19, 19-39 (Christophe Geiger ed., 2015); Orit Fischman Afori, Proportionality - A New Mega Standard in European Copyright Law, 45 InT'L Rev. InTELL. Prop. \& COMPETITION L. 889 (2014); Christophe Geiger \& Elena Izyumenko, Intellectual Property before the European Court of Human Rights, in INTELLECTUAL PROPERTY AND THE JUDICIARY 9 (Christophe Geiger et al. eds., 2018); Christophe Geiger \& Elena Izyumenko, Shaping Intellectual Property Rights through Human Rights Adjudication: The Example of the European Court of Human Rights, 46 MitCHELl HAMLINE L. REV. 527 (2020).. 
law reasoning in copyright matters, a recent and highly commented-upon decision of the French Supreme Court concerning the balancing of freedom of artistic expression with copyright has paved the way for a judicial in concreto assessment of copyright limitations. ${ }^{3}$ This change in approach by the courts can be witnessed not only in France but also in many other civil law jurisdictions across Europe, ${ }^{4}$ and even by the Court of Justice of the European Union (CJEU), ${ }^{5}$ thus strengthening the argument for the introduction of an open clause for limitations in EU copyright law. ${ }^{6}$

In fact, important rulings often result from concrete and simple situations to which judges are required to respond as appropriately and fairly as possible. In this context, the judiciary is increasingly playing a crucial role in the intellectual property arena, allowing the legislative framework to adapt to both

\footnotetext{
${ }^{3}$ Cour de Cassation [Cass.] [supreme court for judicial matters] 1e civ., May 15, 2015, Bull. Civ. 1, No. 13/27391 (Fr.). Discussing this case and the recent case law in France with regard creative appropriations, see also Christophe Geiger, Appropriation créative et droit d'auteur, Réflexions sur les évolutions récentes de la jurisprudence française à la lumière du droit de l'Union et du droit comparé, in MELANGES EN L'HONNEUR DU PROFESSEUR Claude WiTz 327-347 (2018).

${ }^{4}$ See generally Christophe Geiger \& Elena Izyumenko, Copyright on the Human Rights Trial: Redefining the Boundaries of Exclusivity through Freedom of Expression, 45 InT' L ReV. InTELl. Prop. \& COMPetition L. 316 (2014). See also infra Parts I and II.

${ }^{5}$ The cases are too numerous to be cited here. For further references, see Christophe Geiger, The Role of the Court of Justice of the European Union: Harmonizing, Creating and sometimes Disrupting Copyright Law in the European Union, in NEW DEVELOPMENTS IN EU AND INTERNATIONAL COPYRIGHT LAW 435 (Irini Stamatoudi ed., 2016); Jonathan Griffiths, Taking Power Tools to the Acquis - The Court of Justice, The Charter of Fundamental Rights and European Union Copyright Law, in INTELLECTUAL PROPERTY AND THE JUDICIARY, supra note 2, at 144; Stijn van Deursen and Thom Snijders, The Court of Justice at the Crossroads: Clarifying the Role for Fundamental Rights in the EU Copyright Framework, 49 INT'L REV. INTELL. PROP. \& COMPETITION L. 1080 (2018). The importance of fundamental rights when interpreting EU copyright law has been reiterated by the CJEU in a trilogy of decisions rendered on 29 July 2019, Funke Medien NRW GmbH v. Bundesrepublik Deutschland, C-469/17; Pelham GmbH and Others v. Ralf Hütter and Florian Schneider-Esleben, C-476/17; and CJEU, Spiegel Online GmbH v. Volker Beck, C-516/17, excluding however that fundamental rights can serve as external limitations when none of the existing exceptions are applicable (see infra Fn. 8).

${ }^{6}$ Calling for the introducing of an open ended limitation in EU copyright law, see, e.g., Martin Senftleben, The Perfect Match - Civil Law Judges and Open-Ended Fair Use Provisions, 33 AM. U. INT'L L. ReV. 231 (2017); P. Bernt Hugenholtz, Flexible Copyright: Can EU Author's Rights Accommodate Fair Use?, in NEW DEVELOPMENTS IN EU AND INTERNATIONAL COPYRIGHT LAW, supra note 5, at 417; Christophe Geiger, Flexibilising Copyright - Remedies to the Privatisation of Information by Copyright Law, 39 InT'L REV. INTELL. PROP. \& COMPETITION L. 178 (2008); Martin Senftleben, Comparative Approaches to Fair Use: An Important Impulse for Reforms in EU Copyright Law, in Methods AND PERsPeCtives IN INTELleCtuAl PROPERTY 30 (Graeme Dinwoodie ed., 2014); Hugenholtz \& Senftleben, supra note 1; Christophe Geiger et al., The EU Commission's Proposal to Reform Copyright Limitations: A Good but Far Too Timid Step in the Right Direction, 40 EUR. INTELL. Prop. REV. 4 (2018).
} 
technological developments and new social and economic practices. ${ }^{7}$ At a time when legislative solutions are very slow to emerge, and often manifest difficult compromises, the courts can allow a legal field to develop by proposing innovative solutions that amount to a break with established practices. This was certainly the case with the groundbreaking ruling rendered by the French Supreme Court on May 15, 2015 in Klasen v. Malka addressing the relationship between copyright and freedom of artistic expression. That decision constitutes the point of departure for this chapter, as it is symptomatic of a larger trend in civil law countries to legitimize creative uses based on fundamental rights beyond those allowed by statutory limitations to copyright law ${ }^{8}$.

The facts of the case are as follows. The painter Peter Klasen incorporated into his paintings three photographs from an Italian fashion journal showing the face of a young model after coloring them blue. Klasen's process is relatively banal for anyone familiar with the artistic movements of the past 40 or 50 years, in which collages incorporating a range of uses and re-workings of famous trademarks, consumer objects, advertising, fictional characters, and popular works are legion. ${ }^{9}$ In fact, many artists make frequent use of such a process,

${ }^{7}$ On the role of the judiciary in IP law, see the various chapters in Ch. Geiger, C. A. Nard and X. Seuba (eds.), Intellectual Property and the Judiciary, supra note 2, in particular the introduction to the volume p. 1 sq.

${ }^{8}$ This approach has been explicitly endorsed by the Advocate General (AG) of the Court of Justice of the European Union. In his Opinion in Case C-469/17, Funke Medien NRW GmbH v. Federal Republic of Germany, delivered on 25 October 2018 (EU:C:2018:870), AG Szpunar considered that there are circumstances when the exclusive rights "must yield to an overriding interest relating to the implementation of a fundamental right or freedom" - an explicit admittance (for the first time at EU level) of the admissibility of an external limitation to copyright by freedom of expression [at 40]. In his two subsequent Opinions in the "Pelham" and "Spiegel Online" cases, dealing with the question of the admissibility of an external freedom of expressionlimitation beyond the list of codified exceptions in EU Copyright law, the AG specified that there is such an "exceptional circumstance" when the "essence of a fundamental rights" is at stake. See Opinion of Advocate General Szpunar in Case C-476/17, Pelham and Others, delivered on 12 December 2018, EU:C:2018:1002, [94]; and Opinion of Advocate General Szpunar in Case C-516/17, Spiegel Online, delivered on 10 January 2019, EU:C:2019:16, [62]. On these Opinions, see Christophe Geiger \& Elena Izyumenko, Freedom of expression as an external limitation to copyright law in the EU: The Advocate General of the CJEU shows the way, 41 EUR. INTELL. PROP. REV. 131 (2019); unfortunately, however, the CJEU in these cases decided not to follow the AG on this point. Despite showing a favorable position to the possibility of interpreting EU copyright in the light of fundamental rights norms, the Luxembourg court considered in fact that is not possible to go beyond the exhaustive list of limitations by using an external freedom of expression-exception (CJEU, Funke Medien NRW GmbH v. Bundesrepublik Deutschland, C-469/17, 29 July 2019, EU:C:2019:623 (“Funke Medien", at para. 64); CJEU, Pelham GmbH and Others v. Ralf Hütter and Florian Schneider-Esleben, C-476/17, 29 July 2019, EU:C:2019:624 (“Pelham”, at para. 65); and CJEU, Spiegel Online GmbH v. Volker Beck, C-516/17, 29 July 2019, EU:C:2019:625 (“Spiegel Online", at para. 49). On these very important decisions see Christophe Geiger \& Elena Izyumenko, The Constitutionalization of Intellectual Property Law in the E.U. and the Funke Medien, Pelham and Spiegel Online Decisions of the CJEU: Progress, But Still Some Way to Go!, 51 InT’L ReV. INTELl. Prop. \& COMPETITION L. 282 (2020).

${ }^{9}$ On these artistic movements, see, e.g., IRVING SANDLER, ART OF THE POSTMODERN 
primarily by reworking elements protected by intellectual property rights (copyright, trademark, or designs rights) for the purpose of criticism or homage, their aim being to trigger artistic reflection on society and its current icons. ${ }^{10}$ Appropriation plays a central role in the modern and contemporary art movements, even if original works are sometimes modified or transformed. Fortunately, most creative appropriations are not subject to copyright infringement litigation ${ }^{11}$ because, given their frequency, such litigation would likely lead to seizure of the contemporary art collections of many of the world's major museums. ${ }^{12}$

However, such cases occasionally end up before the courts, usually when two factors are present, sometimes in combination. The first is extrinsically linked to the success of the derivative work in question. If it is successful, the author of the appropriated work is likely to consider him or herself legitimately

ERA: FROM THE LATE 1960s TO THE EARLY 1990s (1996). The movement that made use of this approach the most was beyond doubt the one known as "Appropriation Art". See APPROPRIATION (David Evans ed., 2009); EMPRUNTS ET CITATIONS DANS LE CHAMP ARTISTIQUE (Pierre Beylot ed., 2005).

${ }^{10}$ Several scholars have analyzed the intellectual property problems posed by appropriation art, in particular in the context of US copyright law as in the US, a certain number of copyright cases dealt with the delicate issue of what can be appropriated or not in the copyright context. See, e.g., Lynne A. Greenberg, The Art of Appropriation: Puppies, Piracy and Post-Modernism, 11 CARDOZO ARTS \& ENT.L.J. 1, 23-33 (1992); Peter Jaszi, Is There Such A Thing As Postmodern Copyright?, 12 TUL. J. TECH. \& INTELL. PROP. 105 (2009); Judith Bresler, Begged, Borrowed or Stolen: Whose Art is it Anyway? An Alternative Solution of Fine Art Licensing, 50 J. COPYRIGHT SOC'Y USA 15 (2003); William M. Landes, Copyright, Borrowed Images, and Appropriation Art: An Economic Approach, 9 GEO. MASON L. REV. 1 (2000); Darren Hudson Hick, Appropriation and Transformation, 23 FoRDAM InT. PROP. MEDIA \& ENT. L.J. 1155 (2013); Jacqueline Morley, The Unfettered Expansion of Appropriation Art Protection by the Fair Use Doctrine: Searching for Transformativeness in Cariou v. Prince and Beyond, 55 IDEA 385 (2015); Amy Adler, Fair Use and the Future of Art, 91 NYU L. REV. 559 (2016). For a comparative approach, see Christophe Geiger, Freedom of Artistic Creativity and Copyright Law: A Compatible Combination?, 8 U.C. IRVINE L. REV. 101 (2018); André Lucas \& Jane Ginsburg, Copyright, Freedom of Expression and Free Access to Information (Comparative Study of American and European Law), 249 RIDA 5 (2016); Paula Westenberger, Cultural Palimpsests: Artistic Reuses in Brazil in the Context of Copyright and Human Rights (2018) (unpublished Ph.D. dissertation, Queen Mary University of London).

${ }^{11}$ According to one scholar, this could also be the result of the uncertain legal situation with regard to appropriation art, inducing self-censorship in the art world, see Adler, Fair Use and the Future of Art, supra note 10, at 566 (underlining that "the disparate results in these cases, not to mention the high costs of litigating against a backdrop of uncertainty, help explain why a climate of 'self-censorship' has taken hold in the art world”). See also Patricia Aufderheide et al., Copyright, Permissions, and Fair Use in the Visual Arts Communities: An Issues Report 5 (Feb., 2015), http://cmsimpact.org/wp-

content/uploads/2016/01/fair_use_for_visual_arts_communities.pdf (stating that artists "pay a high price for copyright confusion and misunderstanding. Their work is constrained and censored, most powerfully by themselves, because of that confusion and the resulting fear and anxiety.”).

${ }^{12}$ Museums can in addition to the artists also be liable for copyright infringement, as an exhibition can be considered as an act of communication to the public. 
entitled to a share of the fruits of that success. The second is when the appropriation harms the reputation of, or is contrary to the idea behind, the original work or is simply objected to by the original author. The latter occurs primarily in cases in which the derivative work contains a criticism of the primary work. Both factors were present in Klasen v. Malka, in which a fashion photographer brought an action against the painter for infringement of his copyright on the photographs in question. In justifying the appropriation, Klasen, a member of the artistic movement known as Narrative Figuration, ${ }^{13}$ explained that the objective of his artistic approach was to use advertising images in his paintings to provoke reflection by the spectator, thereby putting the initial work in a new context and expressing something entirely new and unexpected. He emphasized that the photographs had been integrated into his work as symbols of excessive consumption.

On the legal side, the painter raised in his defense a series of arguments ranging from the photographs' lack of originality, the quotation, parody, and incidental use exceptions, and, finally, the freedom of artistic expression laid down in Article 10 of the European Convention on Human Rights (ECHR). Although in the first instance the Paris District Court held in effect that the photographs lacked originality, ${ }^{14}$ the Paris Court of Appeal overruled that decision, finding that the choices made by the photographer reflected genuine aesthetic decisions that were an imprint of the his personality as author and, consequently, that the photographs at issue were deserving copyright protection. ${ }^{15}$ The parody, quotation, and incidental/accessory use exception defenses ${ }^{16}$ were all rejected, which is unsurprising given the excessively restrictive interpretation of limitations that has traditionally prevailed in the French copyright system. ${ }^{17}$ The sole defense the painter had left was to claim that the use was legitimated by his right to freedom of artistic expression. However, the Court of Appeal dismissed that argument, holding that there was no higher public interest that would justify the rights of a derivative artist prevailing over those of an original work's author. The court held that freedom

\footnotetext{
${ }^{13}$ This movement often intends to give art a political dimension. On this art movement, see JEAN-LOUIS PRAdel, La Figuration NARRATIVE (2008); SARAH Wilson, THE VISUAL WORLD OF FRENCH THEORY: FIGURATIONS (2010).

${ }^{14}$ Tribunal de Grande Instance [TGI] [ordinary court of original jurisdiction] Paris, Jan. 31, 2012, No. 10/02898 (Fr.).

${ }^{15}$ Cour d'appel [CA] [regional court of appeal] Paris, Pole 5, $1^{\text {st }}$ Chamber, Sept. 18, 2013, No. 12-02480 (Fr.).

${ }^{16}$ On this limitation for "accessory" use created in France by the judiciary without legal basis and allowing the reproduction or representation of a work when it is not the main subject and it is included in the "scenery" of a picture, see Christophe Geiger, Creating Copyright Limitations without Legal Basis: The "Buren” Decision, a Liberation?, 36 INT’L REV. INTELL. PROP. \& COMPETITION L. 842 (2005). The limitation for incidental use is also foreseen in the Article 5(3)(i) of the InfoSoc Directive of 2001.

${ }^{17}$ For a criticism of this restrictive interpretation of limitations and exceptions often used by national courts or the CJEU, but which is not mandated by the copyright legal framework nor the rationale of copyright law, see Christophe Geiger \& Franciska Schönherr, Limitations to Copyright in the Digital Age, in RESEARCH HANDBOOK ON EU INTERNET LAW 110 (Andrej Savin and Jan Trzaskowski eds., 2014); Christophe Geiger, Promoting Creativity through Copyright Limitations, Reflections on the Concept of Exclusivity in Copyright Law, 12 VAND. J. ENT. \& TECH. L. 515 (2010).
} 
of expression can be limited to protect other individual rights and that the reworking of visual material in Klasen's work could not reasonably permit him to ignore the rights of the original photographer. In other words, the Court of Appeal considered the photographer's copyright to limit the painter's freedom of artistic expression.

Klasen appealed the decision, arguing that the limitation on his exercise of artistic expression was disproportionate in comparison with legislators' objective and that the court ought to have assessed the proportionality of the infringement in light of the factual circumstances of the case rather than in an abstract manner ${ }^{18}$. The French Supreme Court supported his argument, and consequently reversed the Court of Appeal ruling based on Article 10 of the ECHR. The Supreme Court criticized the appellate judges for not having explained "in the specific case the manner in which the search for a fair balance between the rights at issue required the decision as pronounced" (emphasis added). With this simple sentence, the French Supreme Court finally put an end to a debate that had been raging for over 15 years on the application of fundamental rights in the intellectual property arena and, more precisely, on the manner in which a fair balance is to be struck between copyright and freedom of expression. ${ }^{19}$

The aims of this chapter are to discuss the evolution in jurisprudential understanding in the EU, and more specifically in France, of the relationship between copyright and freedom of artistic expression and to analyze the courts'

${ }^{18}$ See also in this sense the Advocate General of the CJEU in his Opinion in Funke Medien NRW, supra note 8, [at 31]), stating that "any balancing of copyright against fundamental rights which goes beyond merely interpreting the provisions of copyright law, an exercise on the borderline between the interpretation and application of the law, must [...] be carried out having regard to the circumstances of each individual case", that is to say, on a case-by-case basis which is a standard approach of the human rights courts and ECtHR in particular. According to the Advocate General, "[t]hat case-bycase approach enables the principle of proportionality to be applied as accurately as possible, thereby avoiding unjustified interferences with both copyright and fundamental rights.” (Id.)

${ }^{19}$ See generally P. Bernt Hugenholtz, Copyright and Freedom of Expression in Europe, in EXPANDING THE BOUNDARIES OF INTELLECTUAL PROPERTY: INNOVATION POLICY FOR THE KNOWLEDGE SOCIETY 343 (Rochelle Dreyfuss et al. eds., 2001); Alain Strowel \& François Tulkens (eds.), DROIT D’AUTEUR ET LIBERTÉ D’EXPRESSION, REgARDS FRANCOPHONES, D’EUROPE ET D’AILlEURS (2006); Christophe Geiger, 'Constitutionalizing' Intellectual Property Law? The Influence of Fundamental Rights on Intellectual Property in Europe, 37 INT'L REV. INTELL. PROP. \& COMPETITION L. 371 (2006); CHRISTOPHE GEIGER, DROIT D’AUTEUR ET DROIT DU PUBLIC A L'INFORMATION, APPROCHE DE DROIT COMPARE (2004). For an overview, drawing on the case law of the ECtHR and the CJEU, of the influence of the right to freedom of expression and information on European copyright law in the digital context, see Elena Izyumenko, The Freedom of Expression Contours of Copyright in the Digital Era: A European Perspective, 19 J. WORLD INTELL. PROP. 115 (2016). The debate about the admissibility of a case-by-case approach when evaluating the impact of a copyright restriction on freedom of expression has however been since revitalized by the CJEU in its 3 seminal decisions of 29 July 2019 (supra note 8), declaring inacceptable an external freedom of expression- assessment beyond the codified limitations in EU copyright law, in contradiction with the case-law of the European Court on Human Rights on this matter. 
apparent acceptance of a sort of 'fair use' approach through the application of fundamental rights as external limitations to copyright law. The chapter is divided into three sections following this introduction. The first discusses the application of freedom of artistic expression to copyright law on a case-by-case basis, showing that, although long contested, such an approach is now mandated by the courts, thus significantly "flexibilizing" the legal framework in this area; the second is dedicated to finding a balance between fundamental rights and copyright, with particular attention paid to the weight the judiciary should afford freedom of artistic expression versus copyright in cases of creative appropriation; and the final section discusses and evaluates the growing need for legislative reform to render freedom of artistic expression fully compatible with copyright law in cases of creative reuse.

\section{FAIR USE THROUGH THE APPLICATION OF FREEDOM OF ARTISTIC EXPRESSION TO COPYRIGHT ON A CASE-BY-CASE BASIS: A QUESTION (FINALLY) RESOLVED}

France was, surprisingly, one of the first countries in which first instance judges accepted an argument based on freedom of expression to limit copyright law beyond statutory limitations. In a highly debated decision rendered at the end of the 1990s by the Paris District Court ${ }^{20}$ in the Utrillo case, the judges decided, based on Article 10 of the ECHR, that it was permissible for a television channel to film a number of paintings by Maurice Utrillo when reporting on the opening of an art exhibition dedicated to the artist's work, even if the use exceeded the scope of available exceptions to copyright in that case. ${ }^{21}$ The court considered that showing some of the paintings was inevitable in communicating information about the art exhibition and that it would have been impossible for the channel not to use copyright-protected images when informing the public of the artist's work. ${ }^{22}$ Interestingly, a specific limitation allowing this type of use for information purposes was later introduced, in 2006, in the French Intellectual Property Code ${ }^{23}$ during the implementation process of the Directive on the Harmonisation of Copyright in the Information Society of

\footnotetext{
${ }^{20}$ Tribunal de Grande Instance (TGI).

${ }^{21}$ Tribunal de Grande Instance [TGI] [ordinary court of original jurisdiction] Paris, $3^{\text {rd }}$ Chamber, Feb. 23, 1999, No. 98-7053 (Fr.). For a comment, see Pascal Kamina, Le droit du public à l'information peut-il justifier une exception au droit d'auteur?, RECUEIL DALLOZ 580 (1999). This was the case because of the excessively narrow interpretation of the quotation exception under the French law. More generally on this question see Christophe Geiger, Author's Right, Copyright and the Public's Right to Information, in NEW DIRECTIONS IN COPYRIGHT LAW 24 (Fiona Macmillan ed., 2007) (problematizing the relationship between the author and the recipient of information as it is enshrined in the freedom of expression and the right to information).

${ }^{22}$ Michel Vivant \& Jean-Michel Bruguière, DROIT D’AUTEUR ET DROITS VOISINS 586 n.1 ( $3^{\text {rd }}$ ed. 2015).

${ }^{23}$ Code de la Propriété Intellectuelle [C. Propr. Intell.] art. L. 122-5 (Fr.), translation available at http://www.wipo.int/edocs/lexdocs/laws/en/fr/fr467en.pdf [https://perma.cc/HD7H-G9BP], introduced by law No. 2006-961 of 1 August 2006 concerning copyright and neighbouring rights in the information society. On the scope of this new exception see Christophe Geiger, The New French Law on Copyright and Neighbouring Rights of 1 August 2006 - An Adaptation to the Needs of the Information Society?, 38 INT’L REV. INTELL. PROP. \& COMPETITION L. 401 (2007).
} 
2001 (the so-called InfoSoc Directive), ${ }^{24}$ but it was not available at the time of the Utrillo judgement.

The case went up to the French Supreme Court, which disagreed with externally limiting copyright law through the application of ECHR Article 10, and held that because the legislature had already taken the balancing of fundamental rights into consideration when drafting the copyright law, going beyond that legislative equilibrium was not permissible. ${ }^{25}$ In other words, in the Supreme Court's view, it is impossible to refer to freedom of expression as an external limitation to copyright because that fundamental right had already been internally acknowledged by legislators in drafting the list of exceptions laid down in the French Intellectual Property Code. The same approach was also followed by the Belgian Supreme Court in a judgment on September 25, 2003, in which it held in an abstract manner that "the freedom of expression guaranteed by Article 10 of the European Convention on Human Rights and by Article 19 of the International Treaty concerning Civil and Political Rights does not prevent the protection of a literary or artistic work by copyright.”26

A number of scholars have rightly pointed out that this approach is not compatible with the European legal system and that a fair and proportionate application of fundamental rights requires an appreciation on a case-by-case basis, striking a balance between the specific rights at issue by means of a proportionality test. ${ }^{27}$ In parallel, a number of national judges in several EU countries have indeed embraced the possibility of restricting copyright beyond its internal limits, whether by relying directly on freedom of expression or by combining it with an existing copyright exception, thereby permitting a reevaluation of the limits of copyright protection in light of fundamental rights. ${ }^{28}$

\footnotetext{
${ }^{24}$ Directive 2001/29/EC of the European Parliament and of the Council of 22 May 2001 on the Harmonisation of Certain Aspects of Copyright and Related Rights in the Information Society, 2001 O.J. (L 167) 10 [hereinafter InfoSoc Directive].

${ }^{25}$ Cass. 1e civ., Nov. 13, 2003, Bull. Civ. I, No. 01-14385 (Fr.). For a comment, see Christophe Geiger, France: Intellectual Property Code, Art.L.122-5-3; European Convention on Human Rights, Art.10 - “Utrillo”, 35 InT’L ReV. InTELl. ProP. \& COMPETITION L. 716 (2004).

${ }^{26}$ Cass., 25 Sept. 2003, Auteurs et médias 2004, p. 29. For a combined comment on the two rulings, see André Lucas, Droit d'auteur, liberté d'expression et "droit du public à l'information”, 2005 AUTEURS \& MEDIA 13 (2005).

${ }^{27}$ Pascal Kamina, Droit d'auteur et Article 10 de la Convention européenne des droits de l'Homme, 25 Légicom 15 (2001); CHRISTOPHE GEIGER, DROIT D'AUTEUR ET DROIT DU PUBLIC À L'INFORMATION, APPROCHE DE DROIT COMPARÉ 391-408 (2004). More generally on the use of the proportionality test in copyright disputes, see Christophe Geiger \& Elena Izyumenko, Copyright on the Human Rights Trial: Redefining the Boundaries of Exclusivity through Freedom of Expression, 45 INT'L REV. INTELL. PROP. \& COMPETITION L. 316 (2014). However, some scholars are very critical towards the introduction of the proportionality requirement within copyright law, see, e.g., Lucas \& Ginsburg, supra note 10, at 78 (stressing with further references the "dangers of the proportionality test (...); they are particularly formidable in the field of copyright because the diversity of interest that the courts have to weight increases the need for subjective assessments, a situation which, in the European context, creates legal uncertainty that is harmful both for rightholders and users of works.").

${ }^{28}$ See, e.g., the "Medienprofessor"- Case, Austrian Supreme Court 12 June 2001, [2002] GRUR Int. 341, 33 INT’L REV. INTELL. Prop. \& COMPETITION L. 994; Hague
} 
In some instances, even when the assessment of specific facts did not justify the legitimization of the use at issue, judges have still insisted on imperatively taking the facts of the case into account, stressing that an external conflict between freedom of expression and copyright can arise in certain circumstances. In Ashdown v. Telegraph Group, for example, the London Court of Appeal considered it "necessary for the court to look closely at the facts of individual cases" to accommodate fundamental rights because, under rare circumstances, the right of freedom of expression can "come into conflict with the protection afforded by the Copyright Act." ${ }^{29}$ In the United States, where the fair use-exception allows considerably more flexibility than in the majority of European countries, ${ }^{30}$ the Supreme Court has held that there are circumstances in which a defense based on the First Amendment to the U.S. Constitution, which protects freedom of speech, may be justified. In this respect, even though copyright is traditionally considered "categorically immune" to free speech, ${ }^{31}$ the U.S. Supreme Court softened its position in Eldred v. Ashcroft, ${ }^{32}$ holding that copyright is only "generally immune to free speech," thereby expanding the possibility of using freedom of expression as an limitation in exceptional circumstances.

In Europe, in contrast, the Treaty of Lisbon, which entered into force in 2009, has influenced the use of fundamental rights in the intellectual property area to a considerable extent, ${ }^{33}$ leading to an adjustment to judicial practice in multiple national jurisdictions. In effect, along with the Lisbon Treaty, the Charter of the Fundamental Rights of the European Union and all of its rights, freedoms, and principles have acquired the same legal value as the Treaties of the European Union, ${ }^{34}$ thus integrating the core of EU primary law. Therefore, national judges are required to interpret their internal laws in the light of the fundamental rights afforded by the EU system and, by means of a proportionality test, to ensure a fair balance between the rights in question. ${ }^{35}$

Court of Appeals, Church of Scientology v. XS4ALL, 4 September 2003, 6 AMI 222 (2003); Supreme Court of the Canton of Zurich, Sept. 9, 2004, MEDIALEX 231 (2004); German Constitutional Court, Germania 3, 29 June 2000, GRUR INT. 149 (2001).

${ }^{29}$ See in particular Ashdown v. Telegraph Group Ltd. [2002] EWCA (Civ) 1142 (Eng.) ("Rare circumstances can arise where the right of freedom of expression will come into conflict with the protection afforded by the Copyright Act, notwithstanding the express exceptions to be found in the Act (...) This will make it necessary for the court to look closely at the facts of individual cases”.).

${ }^{30}$ In the context of Appropriation Art, see Morley, supra note 10. For a comparison with the situation in the EU, see Lucas \& Ginsburg, supra note 10, at 32; Geiger, supra note 10 , at 119 .

${ }^{31}$ Harper \& Row Publishers Inc. v. Nation Enterprise, 471 U.S. 539 (1985).

${ }^{32}$ Eldred v. Ashcroft, 537 U.S. 28 (2003).

${ }^{33}$ Christophe Geiger, Intellectual "Property" after the Treaty of Lisbon, Towards a Different Approach in the New European Legal Order?, 32 EUR. INTELL. PROP. REV. 255 (2010).

${ }^{34}$ Treaty of European Union (TEU) art. 6(1), July 29, 1992, 1992 O.J. (C 191),

${ }^{35}$ Christophe Geiger, Copyright's Fundamental Rights Dimension at EU Level, in RESEARCH HANDBOOK ON THE FUTURE OF EU COPYRIGHT 27 (Estelle Derclaye ed., 2009); Dirk Voorhoof, Freedom of Expression and the Right to Information: Implications for Copyright, in RESEARCH HANDBOOK ON HUMAN RIGHTS AND INTELLECTUAL PROPERTY 331 (Christophe Geiger ed., 2015); Bernd Justin Jütte, The 
The CJEU has been very clear about this matter. In Promusicae v. Telefónica, ${ }^{36}$ for example, the CJEU emphasized that EU law demands that member states pay extra attention when implementing directives

...to rely on an interpretation of [directives] which allows a fair balance to be struck between the various fundamental rights protected by the Community legal order. Further, when implementing the measures transposing those directives, the authorities and courts of the Member States must not only interpret their national law in a manner consistent with those directives but also make sure that they do not rely on an interpretation of them which would be in conflict with those fundamental rights or with the other general principles of Community law, such as the principle of proportionality. ${ }^{37}$

National judges are thus expected to interpret their own national legislation and review the scope of their jurisdiction's exceptions to copyright in light of the fundamental rights that are affected. Nevertheless, in some cases such an interpretation might not be possible if no specific statutory exception is available. In these cases, judges must have direct recourse to a fundamental right as a legal basis to legitimate the use at hand and limit copyright "from the outside". Such a situation is particularly likely to arise in EU countries where national intellectual property legislation does not take sufficient account of the fundamental rights in question, particularly where exceptions to copyright are constructed too narrowly.

The European Court of Human Rights (ECtHR) finally eliminated any remaining doubts about this subject in Ashby Donald. ${ }^{38}$ In that case, the Strasbourg judges determined that a prohibition on the communication of works on the Internet, even in breach of copyright, might constitute a violation of freedom of expression. Hence, even in a situation in which there has been clear copyright infringement, it is always necessary to evaluate whether the resulting restriction to freedom of expression is "necessary in a democratic society" so as to strike a fair balance between the different rights at issue. After pointing out that "freedom of expression constitutes one of the essential bases of a democratic society, one of the basic conditions for its progress and the development of each individual," the ECtHR confirmed that "it involves exceptions that in any event require a narrow interpretation, and the need to restrict it must be established convincingly." 39 The court thus made it clear that

Beginning of a (Happy?) Relationship: Copyright and Freedom of Expression in Europe, 38 EUR. INTELL. PROP. REV. 11 (2016).

${ }^{36}$ Case C-275/06, Productores de Música de España (Promusicae) v. Telefónica de España SAU, 2008 E.C.R. I-271, [2008] 2 CMLR 17.

${ }^{37}$ Id. 970.

${ }^{38}$ Ashby Donald v. France, App. No. 36769/08 (Eur. Ct. H.R. Jan. 10, 2013); see also the so called "Pirate Bay" decision (Neij \& Sunde Kolmisoppi v. Sweden, App. No. 40397/12 (Eur. Ct. H.R. Feb. 19, 2013)). For a joint comment, see Geiger \& Izyumenko, supra note 27.

${ }^{39}$ Ashby Donald v. France, App. No. 36769/08, ๆ 38 (Eur. Ct. H.R. Jan. 10, 2013). However, by refusing to take into account freedom of expression beyond the limited list of exceptions in EU copyright law, the CJEU contradicts this position (see supra note 8). It remains to see how this conflict between the approach of both courts will be 
intellectual property rights must be interpreted as exceptions to freedom of expression and that, given the great importance of that freedom within the framework of a democratic society, judges need to be very careful indeed in the presence of a restriction, particularly when it comes to political and artistic speech. ${ }^{40}$

Following these decisions at European level, the development of French case law seemed inevitable. Accordingly, perfectly in line with the ECtHR approach, the French Supreme Court in Klasen demanded that the Court of Appeal explain "concretely the manner in which the search for a fair balance between the rights in question required the decision that it rendered." ${ }^{41}$ It is rather interesting to note that, at approximately the same time in the Netherlands, the Dutch Supreme Court reached a similar conclusion in a remarkable judgment issued on April 3, 2015. ${ }^{42}$ In the case concerned, the Dutch Supreme Court criticized the Court of Appeal for deciding that copyright constitutes a limitation to the freedom of expression established in Article 10 of the ECHR and that only in exceptional circumstances can freedom of expression justify the use of a copyright-protected work beyond the internal limits imposed by law. The Court of Appeal had ruled that exceptional circumstances were not satisfied in the case at issue without explaining why. Hence, the Supreme Court reversed the decision, stating that the appellate court ought to have explainedand verified in the specific case-the manner in which the restriction of freedom of expression was not only proportionate to achieve its results, but also necessary in a democratic society.

resolved, in particular in the light of the future pending accession of the EU to the European Convention on Human Rights. In any case, as it has been emphasized, it "raises the questions of the "constitutionality" of the Luxemburg Court's position in the sense of its compatibility with the EU treaties and the fundamental rights order in the EU" (Christophe Geiger \& Elena Izyumenko, The Constitutionalization of Intellectual Property Law in the E.U. and the Funke Medien, Pelham and Spiegel Online Decisions of the CJEU: Progress, But Still Some Way to Go!, supra note 8, at p. 301).

${ }^{40}$ In this sense, see Christophe Geiger, Fundamental Rights, a Safeguard for the Coherence of Intellectual Property Law?, 35 InT'L REV. INTELL. Prop. \& COMPETITION L. 268 (2004) (recalling that copyright has to be considered "as an island of exclusivity in a sea of freedom" (freedom of expression, freedom of competition)); Helle Porsdam, On European Narratives of Human Rights and Their Possible Implications for Copyright, in 6 NEW DIRECTIONS IN COPYRIGHT LAW 335 (Fiona Macmillan ed., 2007).

${ }^{41}$ Cass. 1e civ., May 15, 2015, Bull. Civ. 1, No. 13-27391 (Fr.). For a comment, see Christophe Geiger, LA SEMAINE JURIDIQUE 967 (2015).

${ }^{42}$ HR 3 april 2015, m.nt. EE (GS Media BV/Sanoma Media Netherlands BV and Others) (Neth.). See in particular para. 5.2.5 of the judgment. 
II. FAIR USE THROUGH FUNDAMENTAL RIGHTS BALANCING: WEIGHING FREEDOM OF ARTISTIC EXPRESSION AND COPYRIGHT IN CASES OF CREATIVE APPROPRIATION

\section{A. Finding a fair balance between copyright and freedom of artistic expression in national courts: towards the legitimization of creative} reuses of copyrighted works

Two highly influential decisions of the Federal Constitutional Court of Germany (BVerfG) also pertain to the issue of creative appropriation and deserve a brief examination here. In Germania 3 and Metall auf Metall, the BVerfG gave important guidance on how to balance copyright and freedom of artistic expression. Germania $3^{43}$ concerned a playwright, Heiner Müller, who had extensively quoted, in italics, from the work of Bertolt Brecht in his play entitled Germania 3. The dispute was brought to the constitutional court, which decided that the use of four pages in total of quoted material from Brecht did not constitute an infringement of copyright because the quotation in question was part of a new creative and artistic work. The BVerfG further stated that legal understanding of the quotation exception needs to be expanded and interpreted more extensively to guarantee the protection of artistic freedom. ${ }^{44}$ In addition, it reinforced the notion that copyright exceptions have to be read in the light of such freedom to strike a balance between various interests. ${ }^{45}$

The highly commented-upon case of Metall auf Metall ${ }^{46}$ centered on the

${ }^{43}$ Bundesverfassungsgericht [BVerfG] [Federal Constitutional Court], June 29, 2000, 3 GRUR INT. 149, § 22 (2001) (Ger.). For non-official English translation, see Elizabeth Adeney \& Christoph Antons, The Germania 3 Decision Translated: The Quotation Exception Before the German Constitutional Court, 35 EUR. INTELL. PROP. REV. 646 (2013).

${ }^{44}$ In paragraph 27 of the decision, the BVerfG clarified that the great mistake of the court of appeal was that it "gives no particular artistic weight to how it is worked into the drama and its position in the play". See Adeney \& Antons, supra note 43.

${ }^{45}$ See Adeney \& Antons, supra note 43 ("The Court states that 'the prohibition placed on the quotation of these two passages represents [the complainants allege] a crude attack on the integrity of Heiner Müller's art work and therefore also on Art 5(3) of the Basic Law' [freedom of art]"); for more decisions that contest the lack of flexibility of the copyright system, see Hugenholtz and Senftleben, supra note 1, (stating that in Germania 3 the Court "held that [...] the quotation right deserves broad application with respect to artistic works. Authors must, to a certain degree, accept that works of art gradually enter the public domain. Copyright exemptions should be interpreted accordingly, and reflect a balancing of relevant interests. In the case at hand, the Court considered, the commercial interests of the copyright owner should give way to the user's interest in providing artistic commentary”.).

${ }^{46}$ Federal Constitutional Court, First Senate, Metall auf Metall, 31 May 2016, 1 BvR 1585/13 (Ger.). For the press release in English, see Federal Constitutional Court, The Use of Samples for Artistic Purposes May Justify an Interference with Copyrights and Related Rights (May 2016), https://www.bundesverfassungsgericht.de/SharedDocs/Pressemitteilungen/EN/2016/b vg16-029.html. For a comment, see Ines Duhanic, Copy This Sound! The Cultural Importance of Sampling for Hip Hop Music in Copyright Law - A Copyright Law Analysis of the Sampling Decision of the German Federal Constitutional Court, 11 GEWERBLICHER RECHTSSCHUTZ UND URHEBERRECHT INTERNATIONALER TEIL 
hip-hop song "Nur Mir," which sampled a continuously repeating two-second rhythm sequence from "Metall auf Metall," a composition by the famous German band Kraftwerk. The Federal Court of Justice (BGH) initially considered the sampling to be an infringing use, and held that the takeover of even the smallest part of a musical composition constituted interference with the rights of the phonogram producers if the reproduction was intended to sound like the original composition. ${ }^{47}$ The BGH also held that simply appropriating a music sample without adding one's own version of it falls outside the limit of free use that could have legitimized the appropriation. ${ }^{48}$ The BVerfG, however, reversed this decision, ruling that the courts have to search for a fair balance between protecting the property interests of phonogram producers and protecting the freedom of artistic creativity to ensure that the latter is not disproportionally affected. The constitutional judges also held that the presumption that the inclusion of any sound sequence in a work interferes with the phonogram producers' rights affords no attention to artistic freedom, and hence is unsuitable for seeking a fair balance between the interests involved. ${ }^{49}$ Finally, the BVerfG ruled that submitting sampling to the authorization of the

[GRUR INT.] 1007 (2016); Marc D. Mimler, “Metall auf Metall” - The German Federal Constitutional Court Discusses the Permissibility of Sampling Music Tracks, 7 QUEEN MARY J. INTELl. Prop. 119 (2017); Neil Conley \& Tom Braegelmann, Metall auf Metall: The Importance of the Kraftwerk Decision for the Sampling of Music in Germany, 56 J. COPYRIGHT SOC’Y U.S.A. 1017 (2009); Mathias Leistner, Die “Metall auf Metall"-Entscheidung des BVerfG - Oder: Warum das Urheberrecht in Karlsruhe in Guten Händen ist, 8 GEWERBLICHER RECHTSSCHUTZ UND URHEBERRECHT [GRUR] 772 (2016); Rupprecht Podszun, Postmoderne Kreativität im Konflikt mit dem Urheberrechtsgesetz und die Annäherung an "Fair Use", Zeitschrift für Urheber- und Medienrecht 606 (2016).

${ }^{47}$ See the two decisions in this case by Bundesgerichtshof [BGH] [Federal Court of Justice] Nov. 20, 2008, Case I ZR 112/06, Metall auf Metall I, translated in Neil Conley \& Tom Braegelmann, Metall auf Metall: The Importance of the Kraftwerk Decision for the Sampling of Music in Germany Part III: Case Translation, 56 J. COPYRIGHT SOC'Y U.S.A. 1017, 1034 (2009); and BGH Dec. 13, 2012, Case I ZR 182/11, Metall auf Metall II, translated in AF, Germany: “Metall auf Metall”, 48 INT’L REV. INTELL. PROP. \& COMPETITION L. 343 (2017).

${ }^{48}$ Gesetz über Urheberrecht und verwandte Schutzrechte [Urheberrechtsgesetz] [UrhG] [Copyright Act], Sept. 9, 1965, BGBL. I § 24 (Ger.). The free use ("Freie Benutzung") limitation permits the author to freely exploit a work created on the basis of another work, provided that "the personal characteristics of the first work are lost in the derived work." Detailed on Article 24 of the German Copyright Act, see Duhanic, supra note 46; VERONIKA FisCheR, Digitale Kunst UND FREIE BENUTZUNG, SYSTEMATISIERUNG UND FLEXIBILISIERUNG (2018). From an international perspective, see Paul Edward Geller, A German Approach to Fair Use: Test Cases for TRIPs Criteria for Copyright Limitations?, 57 J. COPYRIGHT SOC'Y USA 553 (2010). See also Urheberrechtegesetz [UrhG] [Federal Law on Copyright in Works of Literature and Art and on Related Rights] Bürgerliches Gesetzbuch [BGBL] No. 111/1936, § 5(2) (Austria).

${ }^{49}$ Overall, the BVerfG stated that "if the freedom of art development interferes with the rights of phonogram producers only slightly, the interests of the latter should bend in favour of the freedom of art," as translated in Chenguo Zhang, 'Sampling' is Freedom of Art: The German Federal Constitutional Court Deliberates on the Acceptability of Music Sampling in the 'Metall auf Metall' Case, 33 COMPUTER L. \& SEC. REV. 870, 871 (2017). 
right-holder would potentially restrict free artistic activity and cultural development, thereby creating a degree of legal uncertainty for artists ${ }^{50}$.

The German Constitutional Court thus demonstrated far-sighted comprehension of musical development and the particularities of different music styles, as subjecting a use to the exclusive right of phonogram producers would render the use of past sound recordings far more difficult in the future. ${ }^{51}$ Both of these BVerfG decisions demonstrate the court's serious concern for the need to safeguard freedom of artistic expression when developing new musical styles and to determine how a proportional and fair balance must be sought between this fundamental right and the protection of intellectual property rights. ${ }^{52}$ The court also clearly acknowledged the fragility of artistic freedom in the copyright context in these cases, and seemed to recommend that national courts exercise caution when dealing with cases involving creative reuses of copyrighted works.

In the Netherlands, the Hague Court of Appeal also had an opportunity to render a judgment in a 2011 case concerning a conflict between design rights and freedom of artistic expression. ${ }^{53}$ The Danish painter Nadia Plessner had portrayed an African child holding a Louis Vuitton bag to draw attention to the woeful manner in which the Western media was treating the humanitarian crisis in the Darfur region of Sudan, affording more attention to celebrity gossip than to the ongoing genocide (the painting, entitled Darfurnica, also made reference

${ }^{50}$ Note however, that the same case went back to the German Federal Supreme Court, which submitted it on 4 August 2017 to the CJEU for Opinion. As it concerns freedom of artistic creativity in particular at issue, the Advocate General Szpunar came to a different conclusion than the German Constitutional court, considering that, as the EU law stands now, (unlicensed) music sampling should be regarded as a violation of the exclusive rights of phonogram producers and, consequently, as not covered by the "essence" of the right to freedom of expression and freedom of the arts. According to the Advocate General, such stance of EU law towards music sampling and artistic creativity in general might change in the future, but this is the step for the EU legislature, not the Court, to undertake (see Opinion of Advocate General Szpunar in Pelham and Others [at 98]). In its "Pelham" decision, thethe Court of Justice is more nuanced, as is allows sampling if it is non-recognisable, and considers further that the quotation exception could potentially cover recognisable, but "dialogic" use of the original work, subject to certain other conditions (see supra note 8). The exclusion however of an external "freedom of art"-review remains problematic from a fundamental rights perspective. detailed in this sense see C. Geiger, Freedom of Artistic Creativity and Copyright Law: A Compatible Combination?, 8 U.C. IRVINE L. REV. 413 (2018).

${ }^{51}$ On further discussion on music sampling and mash-ups, see Bernd Justin Jütte \& H. Maier, A Human Right to Sample-Will the CJEU Dance to the BGH-Beat?, $12 \mathrm{~J}$. INTELL. PROP. L. \& PRACT. 784 (2017); More generally and on user-generated contents and the enabling of a legal mashup culture, see Bernd Justin Jütte, The EU's Trouble with Mashups: From Disabling to Enabling a Digital Art Form, 5 J. INTELL. Prop. INFO. TECH. \& ELEC. COM. L. 172 (2014).

${ }^{52}$ Surprisingly, in the case of music, on the other side of the Atlantic the flexible Fair use defense seems to have been rarely successful in cases of non-parodic uses. See detailed on the issue Edward Lee, Fair Use Avoidance in Music Cases, 59 B.C.L. REV (forthcoming 2018).

${ }^{53}$ Rb.’s-Gravenhage, 4 May 2011, IER 2011, 39 m. nt. W. Sakulin (Plesner/Louis Vuitton) (Neth.). 
in its structure and title to Picasso's famous Guernica), prompting the luxury fashion house to bring an action for infringement of its design rights on the depicted bag. The Hague Court found in favor of the artist on the basis of freedom of artistic expression, holding that the luxury product depicted in the artwork in this concrete case was being used as a vehicle to express a critical political view endowed with great social significance and, accordingly, that freedom of expression should prevail. ${ }^{54}$

All of these important cases clearly demonstrate that intellectual property law is not weakened when freedom of expression is prioritized. On the contrary, the intellectual property system actually gains legitimacy when exclusive rights are not used to prevent artistic activities and criticism in the form of art. ${ }^{55}$ Moreover, important safeguards exist, most notably the proportionality test conducted to prevent abusive uses of freedom of expression by litigants. It goes without saying that in the Klasen case discussed above, free artistic expression would have been impeded if a prior obligation had been imposed on the painter to contact the owner of the original photographs to ask for permission for the intended use. It is also highly unlikely that the photographer would have been willing to grant such permission, particularly if the artist had explained that his photographs had been chosen to illustrate and criticize the superficiality of the fashion world and the excesses of a consumption-based society! In addition to these practical difficulties, it must be noted that it is not always easy to identify the rights-holder in the case of photography, as photographers (particularly when they work for magazines) often assign their rights to third parties. Therefore, placing the burden of locating rights-holders on the authors of derivative works imposes very high transactional costs.

In fact, it is difficult to imagine Andy Warhol requesting permission from the rights-holder of the Campbell trademark before producing his famous Campbell's Soup Cans with the intention of mocking American consumer society. Or indeed Marcel Duchamp seeking permission from the potential holders of the design rights on the ready-mades he displayed as works of art. Or Jeff Koons asking for the consent of the creators of advertisements to make use of their posters as a way of scorning the messages they wished to communicate. More generally, would it really have been reasonable to require Pablo Picassoand the many other artists who subsequently adapted his work - to ask Édouard Manet's heirs for permission to paint his version of the Le Déjeuner sur l'herbe (a painting whose composition incidentally derived from an engraving by Marcantonio Raimondi, an engraving that was itself based on a drawing by Raphael)? Numerous similar examples can be drawn from the annals of art history. ${ }^{56}$ In a 2007 case, the French Supreme Court had an opportunity to

\footnotetext{
${ }^{54}$ See on this case Jani McCutcheon, Designs, Parody and Artistic Expression - A Comparative Perspective of Plesner v Louis Vuitton, 41 MonASH UnIV. L REV. 192 (2015); Lucie Guibault, The Netherlands: Dafurnica, Miffy and the Right to Parody!, 2 J. INTELL. PROP. INFO. TECH. \& ELEC. COM. L. 236 (2011).

${ }^{55}$ For a fundamental reflection on this, see the fascinating work of GIANCARLO FROSIO, REConciling Copyright With Cumulative CREativity: The THIRD PARADIGM (2018) (examining the long history of creativity in order to demonstrate disparity between cumulative mechanics of creativity and modern copyright policies, and proposing options to reconcile both).

${ }^{56}$ Only the visual arts are mentioned here, but this exercise could easily be transposed
} 
demonstrate the sensitivity of such questions, and did not hesitate to base its decision on freedom of artistic expression in permitting the publication of a sequel to Les Misérables, despite an attempt to prevent it by the heirs of Victor Hugo based on the perpetual moral rights of the renowned writer. ${ }^{57}$

Decisions based on fundamental rights reasoning are becoming increasingly frequent in EU member states, and it is thus anticipated that the importance of seeking a fair balance between copyright and freedom of artistic expression will soon be recognized and affirmed by a majority of Europe's highest courts. Moreover, the use of a proportionality test seems to be the means envisioned by the courts in all of the aforementioned rulings for achieving a fair such balance in light of the factual circumstances of each case. Therefore, it seemed clear that the claim that the conflict between copyright and freedom of expression has been internalized and that no judicial review beyond the existing exceptions is possible belonged to the past. However, as we have noted previously, the CJEU in 2019 has taken a conflicting position, so that this debate has now been revived in the EU. Moreover, acknowledgement of the relevance of striking a fair balance between the interests at stake by several of the highest courts in EU member states has still not translated into general application by courts of lower instance. Such resistance to change is clearly illustrated by developments subsequent to the Klasen decision in France.

\section{B. Resistance to change: the Koons v. Bauret-decisions and judgement of remittal in Klasen}

As previously discussed, applying the principle of proportionality in copyright cases has the potential to legitimize freedom of artistic expression in diverse situations of creative appropriation. ${ }^{58}$ However, a number of trial judges in France have continued to support a more restrictive approach despite the Klasen decision by the French Supreme Court in 2015. The Paris District Court judgment, which was later confirmed by the Paris Court of Appeal, in Koons $v$. Bauret and remittal decision of the Versailles Court of Appeal in Klasen are exactly such cases. As these decisions were the first to apply in concreto balancing and use of the proportionality test, as mandated by a correct application of fundamental rights in the context of appropriation art, they are worthy of detailed analysis. Furthermore, they are also important for a general assessment of this art form from a copyright perspective at the national and international levels.

1. The judgment of the Paris District Court on March 9, 2017 in Koons v Bauret

Koons v. Bauret ${ }^{59}$ centered on a postcard featuring a black-and-white

to all kinds of art, from music, to cinema, to literature, etc.

${ }^{57}$ Cass. 1e civ., Jan. 30, 2007, Bull. Civ. I, No. 125 (Fr.). For a summary of the case in English, see D.W., Copyright Law: France - Victor Hugo II, 38 INT'L REV. INTELL. PROP. \& COMPETITION L. 736 (2007). For a comment, see Christophe Geiger, Copyright and the Freedom to Create - A Fragile Balance, 38 INT'L REV. INTELL. PROP. \& COMPETITION L. 707 (2007).

${ }^{58}$ See Christophe Geiger, Freedom of Artistic Creativity and Copyright Law: A Compatible Combination?, 8 U.C. IRVINE L. REV. 101 (2018).

${ }^{59}$ Tribunal de Grande Instance [TGI] [Paris District court of first instance] Paris, $3^{\text {rd }}$ 
photograph of two naked children holding hands, taken in 1970 by JeanFrançois Bauret, that the American artist Jeff Koons had used as inspiration in 1988 in designing the porcelain sculpture Naked as part of his "Banality" series. The photographer's heirs brought an action for copyright infringement against Koons and the Centre Pompidou, ${ }^{60}$ arguing that the sculpture reproduced the protected photograph in full. Koons did not contest that argument, even though he had added additional elements not present in the original photograph to the sculpture (such as the colored base with flowers and small flower bouquet held by the boy) and cited numerous other sources of inspiration. Many arguments were brought forward as part of the defense, the main one being that the use was legitimated by freedom of artistic expression as protected by Article 10 of the ECHR. A liberal reading of the existing exceptions in EU law, particularly of the right of quotation, would probably have justified the use in question, thus permitting recognition under French law of artistic quotation in the context of a creative reuse of copyright in the interest of protecting artistic discourse. However, because the French courts traditionally have a very narrow understanding of the quotation exception, Article 10 of the ECHR seemed like the best means of legitimating the use under French copyright law. ${ }^{61}$

The Paris District Court welcomed the argument that Article 10 protects freedom of artistic creativity and clarified that assessing the facts on a case-bycase basis is required to guarantee a fair balance between copyright and freedom of expression. This stance was clearly a consequence of the aforementioned Klasen decision, with which the court complied. However, in appreciation of the particularities of the case, and after making a clear reference to fundamental rights balancing mechanisms, the court came to the conclusion that the creative use in question should not be allowed, as Koons had failed to justify the imperative necessity of using Bauret's photograph without seeking the photographer's prior authorization.

Although the decision can be criticized, it must be noted that it shows real progress, as French courts in the past had frequently limited their analysis to an abstract appreciation of the conflict between copyright and freedom of expression, an approach that is not compliant with the method required to balance fundamental rights. An example of this lack of appreciation of the particularities of each concrete case can be seen in the Klasen decision reached by the Appellate Court of Paris. ${ }^{62}$ The court considered, without any further

Chamber, Succession Bauret c. Jeffrey Koons et le Centre national d'art et de culture Georges Pompidou, March 9, 2017, No. 15-01086 (Fr.). For a comment see JeanMichel Bruguière, 348 LEgIPRESSE 177 (2017); Jean-Michel Bruguière, 64 PROPR. INTELL. 69 (2017). The Paris Court of Appeal in a decision of Dec. 17, 2019 (No. 152/2019, 75 PROPR. INTELL. 96 (2020), comment J.-M. Bruguière) simply confirmed the decision of the Paris District court and the factual assessment by the first instance judges without much argumentation, far from a proper proportionality analysis required by article 10 ECHR. Therefore, the following developments will concentrate on the Paris district court decision, not on the Appeal decision.

${ }^{60}$ In fact, the work of art in question was part of the catalogue of an art exhibition devoted to Koons in 2014 by Centre Pompidou.

${ }^{61}$ On the (very contestable) restrictive interpretation of exceptions by Courts at national level, in particular in France, see supra Part I of the chapter.

${ }^{62}$ CA Paris, Pole 5, $1^{\text {st }}$ Chamber, Sept. 18, 2013, No. 12/02480. 
explanation, the copyright protection of the photograph as imposing a limit on the painter's freedom of expression and, as a result, rejected the defendant's argument based on such freedom, as "the rights in the alleged infringing work could not, without a higher interest, outweigh the rights of the works from which they were derived." ${ }^{63}$ The decision was eventually reversed by the French Supreme Court, resulting in the remittal of the case to a lower instance court for an assessment of the concrete facts therein, thus effecting a clean break with previous case law holding that any argument based on a violation of Article 10 of the ECHR that went beyond the scope of existing exceptions should be considered invalid. ${ }^{64}$

Returning to Koons v. Bauret, the Paris District Court began its justification of its ruling by highlighting that, according to the ECtHR, the weight to be afforded the right to freedom of expression is intrinsically linked to the type of discourse used in the given circumstance (political speech enjoying greater protection than commercial speech). The judges considered it necessary to ascertain whether the situation concerned the reuse of copyright for commercial intent or for a higher public interest purpose in order to properly measure the impact on that fundamental right. ${ }^{65}$ In fact, as discussed above, making such a distinction is a very important step when striking a fair balance between the rights at stake, as it permits appreciation of the effects of an eventual restriction on freedom of artistic creativity. It remains evident, nevertheless, that the appropriation at issue was not exclusively a form of commercial expression, which would be the case, for example, in the case of an advertising campaign. ${ }^{66}$ As rightly emphasized by the court, and also in full alignment with the reasoning of the ECtHR, ${ }^{67}$ the fact that Jeff Koons earns money from his art does not lead to the conclusion that his artistic creations have a commercial purpose. ${ }^{68}$

However, the court surprisingly reversed the burden of proof based on its understanding that for freedom of expression to outweigh property rights, the interest being protected must be legitimate and proportional to the ends being achieved and the benefit of a democratic society. This seems to be an incorrect understanding of how ECHR Article 10 is to be applied in copyright cases. Under the rationale of that article, the order in which the burden of proof is

${ }^{63}$ CA Paris, Pole 5, $1^{\text {st }}$ Chamber, Sept. 18, 2013, No. 12/02480.

${ }^{64}$ French Supreme Court, $1^{\text {st }}$ Civil Chamber, 13 Nov. 2003, supra note 25; For a critical comment, see Geiger, supra note 23.

65 TGI Paris, Mar. 9, 2017, No. 15-01086 (Fr.).

${ }^{66}$ Case C-71/02, Herbert Karner Industrie-Auktionen GmbH v, Troostwijk GmbH, [2004] E.C.R. I-03025, \ 51 ("When the exercise of the freedom does not contribute to a discussion of public interest and, in addition, arises in a context in which the Member States have a certain amount of discretion, review is limited to an examination of the reasonableness and proportionality of the interference. This holds true for the commercial use of freedom of expression, particularly in a field as complex and fluctuating as advertising (see, to that effect, Case C-245/01 RTL Television [2003] ECR I-12489, paragraph 73; judgments of the ECHR of 20 November 1989, Markt intern Verlag GmbH and Klaus Beermann, Reports of Judgments and Decisions series A No 165, paragraph 33; and of 28 June 2001, VGT Verein gegen Tierfabriken v Switzerland, Reports of Judgments and Decisions 2001 -VI, paragraphs 69 to 70).”).

${ }^{67}$ See Geiger \& Elena, supra note 2, at 31.

${ }^{68}$ In the same sense, the mere fact that a newspaper is sold to its readers does not amount to a commercial expression. 
analyzed is inverted. Because in this case it was the enforcement of the copyright on the photograph that resulted in the restriction of the American artist's freedom of artistic creativity, it should have been left to the photographer, not the creator of the artistic reuse, to prove that the restriction was indeed necessary and imperative for the benefit of a democratic society. It is evident that freedom of expression holds a privileged position in the EU legal system, and should thus be seen in the context of artistic creativity as a principle from which copyright protection departs. ${ }^{69}$

The court continued its analysis by assessing the justification given by Koons for his use of the specific photograph concerned. Neither the argument that the creative reuse was made with the intention of reflecting upon society nor that Koons' artistic expression had gained a high degree of public acceptance would have been rejected by the court as long as the artist had succeeded in proving that he had conveyed a new and enriching message that would contribute to the development of contemporary art. However, the court considered that the artist had failed to explain in a sufficiently concrete manner the necessity of using the two children in the photograph concerned to spread his message. It seems, in fact, that the court penalized Koons both for his failure to explain why he could not have designed the work differently and for making use of a number of details depicted in the photograph.

The former part of the court's decision is of great importance, as the judges essentially required the artist to provide a convincing justification of his creative process. However, neither the argument concerning the particularities of the artistic movement of which the work of art was a part nor the description of the aim of the individual sculpture or series of sculptures was evaluated with the attention it deserved. Instead, the Paris judges came rather close to judging the artistic merits of the sculpture in question, and even the pertinence and legitimacy of the art movement to which Koons belongs. Indeed, by asking the artist to justify his creative choices, the judges seemed to be assessing his art rather than limiting themselves to matters of law. ${ }^{70}$ It is extremely difficult to evaluate "why an artist could not have done the work of art differently" without entering an area outside legal discourse. This sort of appreciation exceeds a mere request for further information concerning an artistic process of creation. ${ }^{71}$

${ }^{69}$ See more detailed Geiger \& Izyumenko, supra note 27.

${ }^{70}$ Sharing this concern, see Edouard Treppoz, Retour sur la dénaturation contextuelle du Dialogues des Carmélites Comment on Cass. $1^{\text {re }}$ civ., 22 June 2017, G. Bernanos et a. c/ D. Techerniakov, Bel Air Media et a., 352 LÉGIPRESSE 438, 440 (2017) (emphasizing the need "for a fruitful dialogue between the art world and the legal world (...). In the world of art, it is important to analyse the works in question so that the judge can take this analysis into consideration when qualifying the work. In the same sense that a judge is not a technical expert in patents, requiring the help of an expert, the judge is also not an art specialist, which justifies the use of experts in the field". Therefore, this author concludes that the judge has to make his/her decision taking into account the artistic analysis that is subjected to him/her.).

${ }^{71}$ It is conceivable that Jeff Koons might even unable to explain how the use of this particular photograph was necessary for the creation of the work in question. It is possible to imagine that the use of this photograph was so obvious for the artist, in such a way that is not even possible for him to explain the reasons behind this obviousness. To ask an artist to expose or to dissect his creative reasoning and thus to justify his inspiration as to allow judges to appreciate it seems a very problematic step to us, as 
In any case, it is clear that imposing the burden of proof on an artist in this manner entails a strong risk of interfering in the artistic process, potentially leading to a denial of the artist's intellectual and creative freedom. Therefore, judges should be extremely prudent in their rulings when asking for artistic justifications. ${ }^{72}$ That said, in an a contrario interpretation, it could also be deduced that the photograph's reuse might have been deemed legitimate by the court if Koons had been better able to explain the necessity of that reuse.

In Koons v. Bauret, the Paris District Court also made use of another surprising element in establishing the primacy of the photograph's copyright over the derivative work, that is, the fact that it is essential for the public to have knowledge of the primary work in order for the appropriated work to provoke reflection in spectators. Because the photograph was unknown to the general public, such reflection was not possible in this case. The judges thus introduced a distinction between works that are well known, which can easily be appropriated in a lawful manner, and unknown works, for which such a possibility cannot be recognized. Such a distinction is difficult to justify. ${ }^{73}$ It is also contrary to the rationale of the appropriation art movement, whose aim is to cast light on forgotten, outdated, and kitsch works, as well as on any other image or cultural material of a particular time and place that is not expected to be an object of commercial exploitation (for example, a 1970s-era postcard bought at a second-hand shop or flea market or a limited advertising campaign). It thus seems that the Paris court mixed up the requirements of the parody exception, for which a reference to the original work is of major importance, with those of artistically creative re-appropriation, which is protected under Article 10 of the $\mathrm{ECHR}^{74}$.

In fact, the court reached the surprising conclusion in this case that the artist

this sort of appreciation is definitely outside any legal scope.

${ }^{72}$ This was also the position of United States Court of Appeals for the Second Circuit in the Cariou v. Prince- decision, considering that creative appropriation by Richard Prince of the photographs by Patrick Cariou was covered by the fair use exception. Cariou v. Prince 714 F. 3d 694 (2d Cir. 2013). The Court was of the opinion that Cariou had not to justify his creative choices: "What is critical is how the work in question appears to the reasonable observer, not simply what an artist might say about a particular piece of work. Prince's work could be transformative even without commenting on Cariou's work or on culture, and even without Prince's stated intention to do so," id. at 707. Commenting on this passage, see Lucas \& Ginsburg, supra note 10 , at 46 ("[T]he Court's refusal to require artists to explain themselves is certainly compatible with freedom of expression. Artist are not critics- no more than judges areand the copyright law should let their works speak for themselves.”).

${ }^{73}$ In this sense, see also Bruguière, supra note 59, at 72 n.63 ("Why works of art that are unknown should enjoy a supplementary protection in comparison to well-known works?”).

${ }^{74}$ This same surprising argument was re-used by the Paris Court of First instance (TGI) in a decision of 8 November 2018, Koons and Centre Georges Pompidou vs Davidovici (No. 15/02536), in which it was considered that Jeff Koons had infringed the copyright of a photographer when using the image of an advertisement campaign as a point of departure for one of his sculptures. The court found no violation of Article 10 ECHR and no disproportionate restriction of the artist's freedom of artistic expression, as no artistic dialogue was possible since the original work was unknown and thus considered that the artists just wanted to spare a creative effort. 
had used the photograph for personal reasons, that is, to avoid having to be creative himself. Accordingly, it concluded that such use should not have been made without the authorization of the photograph's author and the owner of the copyright on the postcard on which it appeared. The judges seemed to imply that Koons had run out of inspiration and wanted to save himself the effort of creating something new. As previously noted, this conclusion fails to understand the process behind creative appropriation in which the core of a new work is based on an existing work of art. Such appropriation is the creative act (or at least a part of it), and without it the work would lose its raison d'être. Once again, a cautious approach is needed if we are to avoid having the courts define what is or is not a work of art deserving of copyright protection. Assessing the elements that justify a restriction on freedom of artistic expression would have sufficed for the case in question to have arrived at a very different outcome. Moreover, the court completely failed to identify the interests of Bauret's heirs and those of Jeff Koons and to strike a fair balance between their interests and the public interest. Further, no evidence was provided by the deceased photographer's heirs to justify the imperative need to prohibit the public display of Koon's sculpture. Such a prohibition would not only deprive French spectators of access to a major piece of art by a renowned $20^{\text {th }}$-century artist, but would also prevent the artist from publicly conveying his artistic message.

\section{Decision to remit Klasen to the Versailles Court of Appeal}

The decision on the Klasen case by the Versailles Court of Appeal on March 16, $2018^{75}$ raises the same concerns and reservations about implementation of the proportionality test in assessing freedom of artistic expression on a case-bycase basis in copyright cases. The Versailles Court deemed the use of the photographs included in Klasen's painting to be illegal ${ }^{76}$ based on the two rather surprising arguments also used by the Paris District Court in Koons v. Bauret. First, the court stated that it was up to Peter Klasen, who had invoked his freedom of expression in defense, to establish the extent to which a fair balance between the protection of his rights and those of the original work's right-holder should be sought to justify his failure to obtain authorization for use of that work. Second, because of that failure, ${ }^{77}$ the court considered that Klasen's unauthorized use of the photographs in question had not been indispensable for the exercise of freedom of expression he was claiming. As previously noted, this reversal of the burden of proof can be contested under Article 10 of the ECHR, which establishes that the burden of proof rests with the party seeking to restrict such freedom and who, for that purpose, needs to demonstrate that

\footnotetext{
${ }^{75}$ CA Versailles, 1e ch., Mar. 16, 2018, No. 15/06029. For comments, see Jean-Michel Bruguière, LA SEMAINE JURIDIQUE, Mar. 16, 2018, at 513; Valérie-Laure Benabou, DALLOZ IP/IT, 2018, at 300; Christophe Caron, COMM. COM. ÉLECTR, 2018, comm. 32; Pierre Noual, Revue LAMY Droit DE L'IMMATÉRIEL 5193 (2018). For further a comment in English, see Eleonora Rosati, Not Sufficiently 'Transformative' Appropriation of a Photograph Held Infringing by French Court, 13 J. INTELL. PROP. L. \& PRAC. 525 (2018).

${ }^{76}$ On the facts of the case, see in length supra Part I.

${ }^{77}$ On the contrary, the artist even confirmed that the primary work was perfectly capable of being substituted by any other advertising photographs of similar kind for achieving the same means.
} 
the restriction is imperative and not disproportional. Klasen explained sufficiently well that his rationale for using the photographs was to expose how cultural materials convey a message about consumer society. In fact, the use of advertisements has long been the core of pop culture and, more generally, of contemporary art. Nevertheless, in the eyes of the court, this justification was not sufficient. It held that the painter had failed to explain exactly why he had chosen these particular photographs, even though his explanation made it clear that the appropriated material was part of his creative process, if not the heart of his artistic speech. As previously emphasized, such a position taken by the courts risks diminishing the artistic choices that artists should have in exercising their creative freedom.

The Versailles Court then proceeded to analysis of a scholarly position ${ }^{78}$ put forward by the defendant concerning the legal treatment of appropriation art, and arrived at the unexpected conclusion that photographs that are not well known to the public cannot serve as the substrate of such art. This reasoning brings to mind the Paris District Court's decision in Koons v. Bauret, ${ }^{79}$ in which the court held that a primary work had to be known to the public to be used as an object of artistic appropriation. As Valérie-Laure Benabou has pointed out, the judges in these two cases seemed alarmingly interested in assessing the merits of particular works of art, which has traditionally been considered undesirable when it comes to copyright, as judges are not to play the role of art critics. ${ }^{80}$ This is exactly what judges are doing when court decisions consider artistic appropriation legitimate only if the derivative work makes use of a wellknown primary work. ${ }^{81}$ Prof. Benabou emphasized that using notoriety as a yardstick to measure the level of protection a work of art deserves is rather odd. ${ }^{82}$ In reality, it is not the notoriety of a piece of art that might permit its appropriation, but rather the artistic reasoning behind that appropriation. If this stance had been adopted in the two aforementioned cases, the uses would undoubtedly have been deemed permissible.

\section{BEYOND FAIR USE: RENDERING FREEDOM OF ARTISTIC EXPRESSION FULLY COMPATIBLE WITH COPYRIGHT PROTECTION THROUGH LEGISLATIVE REFORM}

The French Supreme Court's decision in Klasen and other national high court decisions applying freedom of artistic expression to limit intellectual

\footnotetext{
${ }^{78}$ Interestingly, the passage discussed in the ruling of the Court of Appeals was extracted from the comments on the decision of the French Supreme Court written by the author of this chapter. See Christophe Geiger, comment on the decision of the French Supreme Court, 15 May 2015, supra note 3, at 1623.

${ }^{79}$ TGI Paris, Mar. 9, 2017, No. 15-01086 (Fr.).

${ }^{80}$ This fear had already been voiced in 1903 by Justice Holmes in Bleistein v. Donaldson Lithographing Co., 188 U.S. 239 (1903) ("it would be dangerous undertaking for persons trained only to the law to constitute themselves final judges of the worth of pictorical illustrations, outside the narrowest and most obvious limits. At the one extreme some works of genius would be sure to miss appreciation."). See also Greenberg, supra note 10, "[I]t is apparent that judges could misconstrue the requirement and deny copyright protection to controversial or innovative works. The requirement does not operate as an incentive for artists to create, but rather discourages new forms of creation.").

${ }^{81}$ Benabou, supra note 75, at 301.

${ }^{82} \mathrm{Id}$. at 302.
} 
property rights have confirmed that the judiciary always needs to adopt a caseby-case approach, even if the use in question lies outside the scope of an exception. However, as we have seen, the debate is not entirely closed as the CJEU decided that limiting copyright beyond the admitted catalogue of exceptions laid out in the InfoSoc Directive is incompatible with EU law. ${ }^{83}$ The recent position of the CJEU risks relaunching another (no less fundamental) discussion on the necessary space devoted to freedom of artistic expression within copyright law, thereby encouraging EU legislators to intervene by exempting certain uses for creative purposes from the scope of protection for an exclusive right. Could such an exemption be achieved by expanding the legal understanding of the existing list of exceptions (specifically, the coverage of quotation and parody) to cover creative appropriations? In fact, the wording of the InfoSoc Directive ${ }^{84}$ is in many respects considerably more flexible than that of many national laws, as the right of quotation was drafted at the EU level as an open concept. It could thus very well allow an assessment of the facts on a case-by-case basis.

Another possibility would be the creation of an entirely new creative use exception to copyright, such as that implemented in Canada ${ }^{85}$ in 2012. Although, as we have seen, the question of allowing the creative use of copyright-protected content remains an extremely sensitive topic in Europe, Canadian legislators did not hesitate in resolving the problem by creating a specific exception for "content not commercially generated by the user." Thus, according to Article 29.21 of the Canadian Copyright Act, "it is not an infringement of copyright for an individual to use an existing work or other subject-matter or copy of one, which has been published or otherwise made available to the public, in the creation of a new work or other subject-matter in which copyright subsists" provided that a certain number of criteria are fully satisfied. The most important criteria are the non-commercial nature of the derivative work and "the absence of a substantial adverse effect, financial or otherwise, on the exploitation or potential exploitation" of the first work, "including that the new work or other subject matter is not a substitute for the existing one." ${ }^{86}$ Although these criteria carefully limit permitted uses, their

${ }^{83}$ CJEU, 29 July 2019, “Funke Medien”, “Pelham”, and "Spiegel Online”, supra note 8. The decisions were rendered upon the request of the Bundesgerichtshof (Federal Supreme Court), Request for a preliminary ruling, Pelham GmbH and others, Case C476/17. For a discussion, see European Copyright Society, Opinion of the European Copyright Society in Relation to the Pending Reference before the CJEU in Case C476/17, Hutter Pelham, https://europeancopyrightsocietydotorg.files.wordpress.com/2018/03/opinion-metall-aufmetall-fin4.pdf (lasted visited January 16, 2019). In his Opinion on this case, the Advocate General Szpunar considers that an external limitation is only admissible in "exceptional circumstances" when the "essence of a fundamental right" is at stake, but estimates that unlicensed music sampling is not covered by the "essence" of the right to freedom of expression and freedom of the arts (Opinion in Pelham and Others, supra note 8, [98]). For a comment see Christophe Geiger \& Elena Izyumenko, Freedom of expression as an external limitation to copyright law in the EU: The Advocate General of the CJEU shows the way, supra note 8.

${ }^{84}$ InfoSoc Directive, art. 5.3(d).

${ }^{85}$ Copyright Act, R.S.C. 1985, c C-42, s. 29.21 (Can.).

${ }^{86}$ Id. ss. 29.21 (1)(a) and (d) respectively. 
reading gives the impression that they will be difficult to implement. In reality, the distinction between commercial and non-commercial use is not always easy to draw, and the absence of an important adverse effect on the exploitation of the first work is subject to a diversity of interpretations. In this respect, one might recall the endless discussions generated by the condition laid down by international law ${ }^{87}$ that an absence of conflict with the normal exploitation of a work is necessary for a copyright exception to be permitted. ${ }^{88}$ Such a condition also seems to be reflected in the wording proposed by the Canadian legislature. ${ }^{89}$ At the same time, however, the condition ${ }^{90}$ also reminds us of one of the four factors that need to be considered in the fair use- defense framework according to U.S. copyright law, namely, the influence of the proposed creative use on the potential market for the protected work. ${ }^{91}$

One might well wonder which of the foregoing solutions is the most worthy of adoption. Without embarking on in-depth analysis of Canadian copyright law, ${ }^{92}$ it could be pointed out that the exception in Article 29.21 of the Canadian Copyright Act constitutes an attempt to internalize the conflict between freedom of expression and copyright within a particular legislative provision. Thus, the Canadian approach responds directly to certain commentators' preoccupation

\footnotetext{
${ }^{87}$ Namely the second condition of the three-step test, "provided that such reproduction does not conflict with a normal exploitation of the work".

${ }^{88}$ Specifically Art. 9.2 of the Berne Convention (for the right of reproduction), Art. 13 of the Agreement on Trade-Related Aspects of Intellectual Property Rights (TRIPS Agreement)(for all property rights) and Arts. 10 and 16 of the WIPO treaties on Copyright (WCT) and Performing Rights and the Rights of producers of Phonograms (WPPT), laying down the so-called three step test. See on this question Christophe Geiger et al., The Three-Step-Test Revisited: How to Use the Test's Flexibility in National Copyright Law, 29 AM. U. INT'L L. REV. 581 (2014); See also Christophe Geiger, The Role of the Three-Step Test in the Adaptation of Copyright Law to the Information Society, UNESCO E-COPYRIGHT BULLETIN, Jan.-Mar. 2007, available at http://unesdoc.unesco.org/images/0015/001578/157848e.pdf.

${ }^{89}$ Which however has not prevented certain commentators from arguing that Art. 29.21 does not respect the criteria imposed by international law. See on this question Peter Yu, Can the Canadian UGC Exception Be Transplanted Abroad?, 26 INTELL. Prop. J. 175 (2014) (putting forward very serious arguments in favour of the compatibility of the provision with the three-step test).

${ }^{90}$ On the conditions for the fair use defense in copyright matters, see Bernd Justin Jütte, The EU's Trouble with Mashups: From Disabling to Enabling a Digital Art Form, 5 J. INTELL. PROP. INFO. TECH. E-COM. L. 172 (2014).

${ }^{91}$ Art. 107 of the American 1976 Act. It must be noted that in the Campbell v. Acuff Rose judgment, the Supreme Court held that the re-use of a chorus from the song "Pretty Woman" by a hip-hop group parodying the famous song by Roy Orbison constituted fair use, holding that the fourth criterion was not necessarily the most important and that all the criteria should be applied in the light of the objective pursued by copyright, namely the promotion of progress in science and useful arts. Campbell v. Acuff-Rose Music, Inc., 510 U.S. 569 (1994). The lawful use for creative purposes was thus admitted despite the fact that this was a "commercial" use, mainly because the work was of a "transformative" nature.

${ }^{92}$ See, in particular, amongst the many commentaries, Theresa Scassa, Acknowledging Copyright's Illegitimate Offspring: User-Generated Content and Canadian Copyright Law, in THE COPYRIGHT PENTALOGY: HOW THE SUPREME COURT OF CANADA SHOOK THE FOUNDATIONS OF CANADIAN COPYRIGHT LAW 431 (Michael Geist ed., 2013).
} 
with the multiplication of conflicts outside copyright law, i.e., in the field of fundamental rights or competition law. However, such internalization through the implementation of a new exception for uses made for creative purposes is not a new idea. ${ }^{93}$ In fact, it was clearly considered to be a potentially viable option by the European Commission ${ }^{94}$ a good decade ago, and was also envisaged as a possibility by the European Parliament in a resolution dated July 9, 2015. ${ }^{95}$ In the same spirit, a group of European academics working on the European Copyright Code project proposed the adoption of a general clause covering all uses justified by freedom of expression that are not provided for by existing EU legislation. ${ }^{96}$ Recently, scholars have proposed to implement a new use privilege for User-Generated Content which combined with the obligation to pay equitable remuneration would satisfy all requirements of international copyright law such as the three-step test and create a new revenue streams for creators ${ }^{97}$. Other more classical options have also been considered. In France, for example, the "Lescure” report suggested the development of existing

${ }^{93}$ More generally, the idea that copyright, through the many exceptions that it includes, already regulates within itself all the conflicts that could oppose it to other rights, is moreover advanced to dismiss the idea that such conflicts can be taken into account outside the legal provisions. But, who can seriously believe in a legislature that has foreseen everything? For this reason, the Advocate General of the CJEU has recently admitted that there are exceptional circumstances that justify an external limitation of copyright through fundamental rights, while still considering that "in the normal scheme of things, the internal limits on copyright make it possible to reconcile, in a satisfactory way overall, fundamental rights and freedoms with the exclusive rights of authors as regards the use of their works". See Opinion in Case C-469/17, Funke Medien, supra note 8, Par. 40. On this issue see detailed Christophe Geiger \& Elena Izyumenko, Freedom of expression as an external limitation to copyright law in the EU: The Advocate General of the CJEU shows the way, supra note 8.

${ }^{94}$ Green Paper of the Commission of the European Communities, Copyright in the Knowledge Economy, COM 466 (2008).

${ }^{95}$ European Parliament Resolution of 9 July 2015 on the implementation of Directive 2001/29/EC of the European Parliament and of the Council of 22 May 2001 on the harmonisation of certain aspects of copyright and related rights in the information society P8_TA-PROV(2015)0273, in which the European Parliament "notes with interest the development of new forms of use of works on digital networks, in particular transformative uses, and stresses the need to examine solutions reconciling efficient protection that provides for proper remuneration and fair compensation for creators with the public interest for access to cultural goods and knowledge” (Paragraph 42). For a comment, see Christophe Geiger et al., The Resolution of the European Parliament of 9 July 2015: Paving the Way (finally) for a Copyright Reform in the European Union? 37 EUR. INTELL. PROP. REV. 683 (2015).

96 The Wittem Project: European Copyright Code, art. 5.2 (April 2010), http://www.copyrightcode.eu. See in particular Thomas Dreier, The Wittem Project of a European Copyright Code, in CONSTRUCTING EUROPEAN INTELLECTUAL PROPERTY: ACHIEVEMENTS AND NEw PERSPECTIVEs 292 (Christophe Geiger ed., 2013).

${ }^{97}$ See Martin Senftleben, User-Generated Content - Towards a New Use Privilege in EU Copyright Law, in RESEARCH HANDBOOK ON INTELLECTUAL PROPERTY AND DIGITAL TECHNOLOGIES, 136 sq (Tanya Aplin, ed., 2020); Joao Pedro Quintais, COPYRIGHT IN THE AGE OF ONLINE ACCESS, ALTERNATIVE COMPENSATION SYSTEM IN EU LAW, 2017 (in particular Chapter 6, p. 365-406), and from the same author: Rethinking Normal Exploitation: Enabling Online Limitations in EU Copyright Law, AMI - tijdschrift voor auteurs-, mediaen informatierecht 2017/6, pp. 197-205. 
exceptions (the quotation and parody exceptions in particular) as a way to "ease the conditions in which the protected works can be reused in order to create derived works and to distribute them within a non-commercial framework"98 while still complying with InfoSoc Directive. ${ }^{99}$

Whatever solution is adopted, it would be desirable to increase the flexibility of and role granted to freedom of artistic expression within copyright law to better adapt legal provisions to the factual circumstances of various art movements. The failure of copyright law to take sufficient account of fundamental values such as freedom of expression ultimately risks the rejection of the entire system by creators and the general public alike if no appropriate solution is implemented. ${ }^{100}$ In this context, the argument put forward by several scholars that flexible exceptions are not within the continental tradition, and risk increasing legal uncertainty, is not convincing as numerous other open norms can be found in continental legal systems. ${ }^{101}$ Moreover, the uncertainty that an open provision can generate should not be overestimated. Even in the United States, whose copyright system is often presented as difficult to predict owing to the fair use clause, empirical studies over the past decade have shown that the solutions adopted by the courts can be forecast in most cases, largely disproving certain preconceived ideas on the matter. ${ }^{102}$ The fact that more than 40 countries worldwide have adopted open clauses within the copyright arena, ${ }^{103}$ and that many of those countries boast flourishing cultural industries,

98 PierRe Lescure, Mission «ACTE II DE L’EXCEPTION CULTURELLE», CONTRIBUTION AUX POLITIQUES CULTURELLES A L'ERE NUMERIQUE 36 (2013).

${ }^{99}$ The Directive in fact proposes the right of quotation as an open concept, permitting an assessment on a case-by-case basis (Art. $5.3 \mathrm{~d}$ requires the use to be "in accordance with fair practice, and to the extent required by the specific purpose"). This is very close to a "fair use" condition. In this line, some scholars have actually defended recently the idea that the right of quotation as included in international copyright law is very similar to a "fair use" provision. See the interesting chapter by Tanya Aplin \& Lionel Bently, Displacing the Dominance of the Three-Step Test: The Role of Global, Mandatory Fair Use, in this volume.

100 See in this sense Christophe Geiger, Reconceptualizing the Constitutional Dimension of Intellectual Property: An Updatein INTELLECTUAL PROPERTY LAW AND HuMAN RighTS 117 sq (Paul L.C. Torremans ed., 4th ed. 2020).

${ }^{101}$ For example, the French author's right tradition often accommodates itself very well with open concepts. As an example, the extremely subjective criterion of originality is frequently the source of uncertainty, often making it impossible to know in advance if a work will be protected by copyright or not (it is then necessary to wait for the judge to make a decision, often at the end of very long proceedings; see on this question Vivant \& Bruguière, supra note 22, at 260; these authors also ask whether originality is not an "elusive concept", $i d$. ๆ 258. Open norms constitute the special feature of any law that claims to be dynamic and adaptable. Continental civil laws are full of it, far beyond the field of copyright, see CÉLINE CASTETS-RENARD, NOTIONS À CONTENU VARIABLE ET DROIT D'AUTEUR (2004).

${ }^{102}$ Matthew Sag, Predicting Fair Use, 73 OHIо ST. L.J. 47 (2012); Barton Beebe, An Empirical Study of U.S. Copyright Fair Use Opinions, 1978-2005, 156 U. PA. L. REV. 549 (2008); Pamela Samuelson, Unbundling Fair Uses, 77 FORDHAM L. REV. 2537 (2009).

${ }^{103}$ For the list of these countries and their legislation, see Jonathan Band \& Jonathan Gerafi, The Fair Use/Fair Dealing Handbook (Mar. 2015), http://infojustice.org/wpcontent/uploads/2015/03/fair-use-handbook-march-2015.pdf [https://perma.cc/489F- 
should serve to mitigate concerns and definitively permit a different view concerning open-ended clauses to limit copyright. However, the mere transplant of a U.S.-type fair use provision would admittedly not be ideal, as the copyright systems on the two sides of the Atlantic, despite certain convergences, ${ }^{104}$ remain different in scope and spirit. ${ }^{105}$ Thus, as has been recently proposed, a more promising way forward-and one that is more compatible with the EU legal system - might be to codify the criteria already used by judges when balancing fundamental rights and copyright law and introduce a European fair use provision based on freedom of expression in the EU acquis in addition to the existing list of exceptions. ${ }^{106}$

More fundamentally, it might be necessary to think ahead and carry out a more in-depth review of the mechanism of exclusivity in the context of a derivative creation, even if doing so means considering other options for the remuneration of a work's original authors. ${ }^{107}$ This fascinating, albeit complex, issue is beyond the scope of this chapter. Whatever solution is adopted, it must necessarily guarantee that copyright (and, more generally, intellectual property law) cannot under any circumstances be misused for the purpose of censorship, regardless of whether the expression in question has political, cultural, or artistic intent. ${ }^{108}$ All in all, one thing appears quite obvious: it can hardly be considered compatible with free artistic creativity in a democratic society to demand that artists seek authorization before creating a new work.

\footnotetext{
MYUK].

${ }^{104}$ See Gillian Davies, The Convergence of Copyright and Authors' Rights - Reality or Chimera?, 26 InT’L ReV. InTELL. PROP. \& COMPETITION L. 964 (1995).

${ }^{105}$ See in this sense Paul L.C. Torremans, The Perspective of the Introduction of a European Fair Use Clause, in CODIFICATION OF EUROPEAN COPYRIGHT LAW: ChALlenges AND PersPeCtives 319 (Tatiana-Eleni Synodinou ed., 2012).

${ }^{106}$ See detailed for such a proposal Christophe Geiger \& Elena Izyumenko, Towards a European "Fair Use” Grounded in Freedom of Expression,35 Am. U. Int'l L. Rev 174 (2019) .

${ }^{107}$ See on this issue Christophe Geiger, Les limites au droit d'auteur en faveur de la création dérivée, in COPYRIGHT AND FREEDOM OF EXPRESSION: PROCEEDINGS OF THE ALAI STUDY DAYs 338 (2008); Christophe Geiger, Promoting Creativity through Copyright Limitations, Reflections on the Concept of Exclusivity in Copyright Law, 12 VAND. J. ENT. \& TECH. L. 515 (2010); Christophe Geiger, Statutory Licenses as Enabler of Creative Uses, in REMUNERATION OF COPYRIGHT OWNERS, REGULATORY ChAlLENGES OF NEW Business MODELS 305 (Kung-Chung Liu \& Reto M. Hilty eds., 2017). See Christophe Geiger, Freedom of Artistic Creativity and Copyright Law: A Compatible Combination?, 8 U.C. IRVINE L. REV. 101 (2018) (advocating a "limitation based"-statutory remuneration system for commercial creative uses, administrated by an independent regulation authority which could solve ex post disputes between original and derivative creators on the price to be paid for the transformative use via mediation, taking into account the existing and expected revenue streams for the derivative work).

${ }^{108}$ For a reflection in this sense in order to redesign copyright as an access right, see Christophe Geiger, Copyright as an Access Right, Securing Cultural Participation through the Protection of Creators' Interests, in WHAT IF WE COULD REIMAGINE COPYRIGHT? 73 (Rebecca Giblin \& Kimberlee Weatherall eds., 2016).
} 